\title{
Culture and Consumerism in Jean Baudrillard: A Postmodern Perspective
}

\author{
Munther Mohd. Habib ${ }^{1}$ \\ ${ }^{1}$ Department of English Language, Literature and Translation, Zarqa University, Zarqa, Jordan \\ Correspondence: Professor Munther Mohd. Habib, Department of English Language, Literature and Translation, \\ Zarqa University, Zarqa, Jordan. E-mail: malqaryouti@gmail.com
}

Received: May 17, $2018 \quad$ Accepted: June 22, $2018 \quad$ Online Published: August 31, 2018

doi:10.5539/ass.v14n9p43 URL: https://doi.org/10.5539/ass.v14n9p43

This research is funded by the Deanship of Scientific Research at Zarqa University-Jordan.

\begin{abstract}
Postmodernism is a very deceptive term. It is very hard to define the term as it encompasses various meanings for various critics. The critics like Michel Foucault, Jean Baudrillard, Jean Lyotard and Jameson attempt to define postmodernism in terms of culture and consumerism. Baudrillard's Simulacra and Simulacrum is a vital work to define modernism in terms of culture and consumerism. The present paper attempts to study culture and consumerism in Jean Baudrillard's work. The paper concludes that the postmodern society carried out death in all aspects of life.
\end{abstract}

Keywords: culture, Consumerism, hype reality, simulacra

\section{Introduction}

Jean Baudrillard (b.1929), a cultural critic and media intellectual, claims that the contemporary culture is postmodern. It is marked by plurality, diversion, intense fragmentation, and indirection. He discovers that it is mass media that create demands and seduction of objects and ultimately make the contemporary society a powerful consumer society. Media have shaken the very foundation of postmodern culture, giving a new direction to reality. Baudrillard describes that the relationship between the real and simulacra has undergone a sea change in the contemporary society. Now the very concept of a true copy is thrown into the wind. Models and simulacra have become reality. In the postmodern media and consumer society, everything becomes an image, a sign, a spectacle, a transaesthetic, transpolitical, and transsexual. The present paper makes an investigation as to how Baudrillard focuses his critical attention on the four points-(i) postmodern society is the society of communication established by mass media; (ii) postmodern society is a consumer society and (iii) the culture of postmodern society is based on simulation or simulacra or hyperreality, and (iv) postmodern society is nearing the fractal order.

Deeply influenced by Saussure, Durkheim and Freud, Baudrillard starts as a Marxist sociologist, but later on like his contemporaries, such as Althusser and Lyotard, he analyses Marxian capitalist production in the light of structuralist theory of production and circulation of signs. But again after the tumultuous events of 1968, such as No Bra Day in May celebrated by miniskirt clad American women by burning brassieres and under-wears, he gets disillusioned and disoriented. There undergoes a radical change in his Marxist-structuralist stance, which is inadequate to analyze the fundamental of the contemporary society. He develops a broader and more analytical outlook toward society. He argues that there is a rupture between modernity and postmodernity, marked by cyberculture. This culture is completely in the clutch of mass media, pestering and victimizing the individual. Baudrillard finds Marx's economic philosophy incapable of explaining life in the late capitalist societies, because they are based on consumer. Throughout his life, Marx lays emphasis on the mode of production so much that the other aspect of capitalism i.e. consumer and culture slips from his mind. Baudrillard, by the way, supplements it by consumer, the focal point of his discussion. Now there is a shift from production to consumerism. This idea - the analysis of society through consumer and culture - occurs to his mind during his sojurn in America and writes a travelogue America in the lifestyle of the Americans. He declares America the greatest consumer society and model for the rest of the world.

\section{Discussion}

To explain postmodern society through the analysis of consumer and culture, Baudrillard takes the help of 
structuralism and semiotic. His works-The System of Objects, The Society of Consumption and For aCritique of the Political Economy of the Sign - combine a semiotic and structuralist study of culture with a neo-Marxist analysis. Baudrillard's view of object, therefore, is quite different from that of Marx. For Marx an object becomes commodity and has natural use-value. It has also exchange value and can be exchanged for money. But Marx fails to pay any attention to the symbolic and semiotic aspect of the object. On the other hand, Baudrillard explains an object with a semiotic analysis - an analysis of the meaning of the object. To him an object has $\mathrm{s}$ sign-value. Marx evaluates object on the basis of utility, value and durability i.e. emphasis on use-value, whereas Baudrillard argues that value is based on sign or simulation. Thus, he distinguishes "between a metallurgic and semiurgic form of society, that is based on the material manufacture of commodities as opposed to one based on the production and circulation of signs in the form of information." (Jim Powell 31).

In other words, when a consumer buys an object, it signifies something more than a commodity. An object, no doubt, has use-value, but at the same time it stands for a sign of the consumer's prestige, rank, and social understanding. An individual, after all, has a deep desire to distinguish himself from other human beings through the system of social differentiation. For members of tribal cultures the differences might be displayed by the use of certain tattoos or feathers. But in postmodern society, the consumer displays what he buys, in order to differentiate himself socially. A need for the particular object is thrown into the background and the need for social difference or meaning comes to the fore. The purchase of the object ceases to be a natural need, differentiating the buyer socially from other people, and integrates him systematically into a homogenous level of society, a level of society in which everyone uses the same object. Perpetually, one group vies with another in consuming the quantity and quality of commodities. This act of consumption is further enhanced by a number of increasingly familiar features: extended credit facilities, share ownership, segmented markets, enticing offers and rebates, volatile consumer preferences, the rise of consumer organization, pressure groups and media 'watch dog' organize around issues of consumer rights. These developments are conducive to mass consumerism, and in turn affect the nature of commodities and the policies of producers.

In postmodern society, when a consumer buys an object, he is buying into a whole system of needs that is at once rational and hierarchical. The aim of the modernist society was to establish a classless society removing all differentiation, but the present society is fragmented because consumer objects create hierarchy and groups in it. The value or price of the object is determined by sign-value. Object is not concerned with utility or durability as much as concerned with sign. In the market objects are not sold, but sign. An individual's recognition depends on which consumer object he uses. On the surface, it appears that the consumer is free to buy anything, but it does not happen so because every individual is unique and wants to be equal in his own group. He loans but never lets him go below the level of his own hierarchy. Constantly under the pressure of sign, he succumbs to it. The consumer consumes sign, not the object. In this way, consumption is not natural but cultural and rather becomes conspicuous consumption as held by Veblin.

The consumption, display, and the use of objects operate on the basis of cultural codes. Previously the labour was exploited, now the consumer. It is nothing but an incarnation of capitalism. This desparate consumption of objects or commodities, this search for being, meaning and prestige makes man boring, fatigued, alienated, and he thinks of bringing a radical change in society. Sheer consumption cannot yield joy and happiness but sometimes leads to an abnormal human behaviour. Other structuralists and postmodernists-Claude Levi-Strauss, Roland Barthes and Paul Du Gay also underline the present society in terms of consumerism and culture.

Baudrillard holds mass media or cyberculture accountable for creating a society of consumerism. This culture is made of disparate fragmentary experiences and images of music video, television, computer, Internet, and numerous other information technologies. They imprint a tremendous effect on postmodern economic systems creating widespread demand of objects. Media have rocked the very root of postmodern culture, giving a new direction of reality. Baudrillard in The Orders of Simulacra describes that the relationship between the real and simulacra has undergone a radical change in the new condition of media-saturated society. It is heedless to the logic of representation, lacking a fixed referent or ground. The 'cybernatization' produces floating signifier that is a departure from the traditional understandings of sign.

Simulacra mean copies of real objects or events. Now there is no carbon copy, the very concept of the carbon copy is thrown into the wind. Models and simulacra have become reality itself. That is why "the cinema and T V are America's reality" (Jere Paul Surber 222). The Canadian media theorist Marshall MacLuhan in an interview with Playboy also observes that television "tattoos its message directly onto our skin." Media have become a main culprit and have taken postmodern man so far that he has forgotten the real. Rather he is hooked into simulacra of reality. In America Baudrillard observes: 
Everything is destined to reappear as simulation. Landscape as photography, women as the sexual scenario, thoughts as writing, terrorism as fashion and the media, events as television. Things seem only to exist by virtue of this strange destiny. You wonder whether the world itself is not just here to serve as advertising copy in some other world (Jean Baudrillard 32).

In the world of cybernetization, consumerism and commercialization, postmodern societies flowing with the images of media are drowned in the spirit of ecstasy. These signs have no resemblance to reality. The dazzling spectacle of the mediaspace creating a nightmarish vision unearths surface glitter, emptiness and hollowness. Michael Kelly writes: "everything becomes an image, a sign, a spectacle, a transaesthetic — just as everything also becomes transeconomic, transpolitical, and transsexual (Jean Baudrillard 104).

Simulacra or simulations do not occur all of a sudden. The relationship between the real and the simulacra has changed through history step by step. Profoundly impressed by Foucault's The Order ofThings, Baudrillard describes the distinct orders of simulacra. During the feudal era, it was a closed society, organized by a relationship to a system of fixed hierarchies of signs, which were limited in number and supposedly divine. In such a society one was assigned to a fixed social space, like a caste, and mobility between social classes was impossible. A serf, labouring in the fields, could not become a knight. In other words, it would reflect the basic reality.

Then, in the period of early modernity, from the Renaissance to the beginning of the industrial Revolution, the rigid order of the feudal era broke down due to the rise of bourgeoisie. During this period, images, signs, and symbols were not divine but artificial and proliferated in the fields of theatre, fashion, art, and politics as the new rising class attempted to create the world in its own image, in its own naturalized world. Thus, in the first order of simulacra, signs were taken to represent the external reality of nature; still referring to the original extends their scope. The second order of simulacra appears with the advent of the Industrial Revolution. The simulacra now become limitlessly reproducible through mechanical and industrial mass production of commodities of exact replicas. All of which have equivalent value.

In Baudrillard's view, at the end of the twentieth century, society is passing through the third order of simulacra known as hyperreality - somehow related to the digital. It is "an artificial yet heightened sense of reality," (Michael Kelly 218) a condition, a state, an effect, and the most developed form of simulacra. The swirling images are produced and reproduced in such a way that they are preferred to their original i.e. the copies or simulacra are more real than the real. They acquire "more legitimacy, value and power than the original themselves" (Jim McGuigan 153). Thus, the sudden explosion of new technologies, particularly, mass media paves a healthy ground for new reality. Pointing to an implosion, effect, Baudrillard despairs that images and reality implode and images become reality. Serber comments:

Numerous examples of this implosion of images and reality in postmodern culture can be cited: infotainment, infomercials, docudramas, and of course, virtual reality are all by now familiar genres in which the boundaries between image and reality have been obscured or erased (Victor E. Taylor \& Charles E. Winguist 183).

In Simulation and Simulacra (1981), Baudrillard argues that hyperreality is autonomous and free from all references to the real, and there exists no distinction between the images and their referents. Also in the essay, "The Precession of Simulacra,' he articulates that postmodern culture breeds 'the society of the image,' which is frantically searching for the real badly eroded. Baudrillard is pessimistically confident of this effort as meaningless and futile, because the media dominated society would return with nothing but an "exacerbated experience of hyperreality." Baudrillard sees other aspects to hyperreality: simulation is make-believe that one has something that he/she doesn't have. It also reminds of Umbesto Eco (b.1932), the Italian semiologist who holds that hyperreality is associated especially with cultural tendencies and a prevailing sensibility in contemporary American society. In his essay "Travels in Hyperreality" (1980), he detects "the Absolute Fake" from the vacuum of the present depthless society. This society of 'consumerism' produces the new 'ambience' of the shopping mall and an emblematic scene of contemporary mentality when consumers are seduced and stupefied all at once by the display of diversity.

What characterizes Baudrillard's perception about the postmodern world is grim and gloomy. Unlike the modernist thinkers, he rejects the concept of the progress of humanity and history. In Symbolic Exchange and Death (1976), his apocalyptic vision signals the death and destruction of the contemporary society. It is a dazzling but wounded, fractured, hypocrite and indefinable society, a kind of mayanagri, a Disneyland, where nothing exists except fantasy. Production in huge quantity, formation of metropolitan cities, globalization, new neighbours, diversity, flexibility, pluralistic cultures are waxing without any tinge of hope, depth, form, and progress of the society. All traditional and modernist ideas and values are shattering into pieces. Man is destined 
to dwell in glamorous cyberculture, a culture-fragmented, shallow, and rudderless, where everything is available to be purchased except peace, cheerfulness and satisfaction. Thus, he is growing more and more inert and bored; the spirit of revolution is gradually dwindling. Jere Paul Surber spells out:

The postmodern individual becomes merely an exhausted indifferent and passive observer of the cultural spectacle to which it is continually subjected, a mere channel through which passed a meaningless bacchanal of the most diverse images and information, which ultimately signify nothing. Postmodern culture's extreme diversity and variety is, a monolith of meaningless substitutions of one image for another a fractal structure where apparent depth is continuously being dissolved by endless repetition, in every cultural domain and at every cultural level, of the some monotonous cycle of substitutions (Jere Paul Surber 223).

There is no way-out but to sleep and awake with the information of computer and television. Watching TV has become a discipline, a culture, and an instinct. Influx of files, videos, serials, and other electronic communication technologies, particularly, Internet, breed images and signs which are floating in great speed, flow and flux all over the world all the time. They are nothing but images devoid of depth, coherence, and originality. Human mind, like a black box, wittingly or unwittingly, is perpetually recording those images. In TheMedium Is the Message: An Inventory of Effects (1967), MacLuhan describes a world remade by electronic media in which the individuals are battered by an endless stream of information. He claims that "television and telephone had the effect of transmitting the communicator rather than the communication" (Ibid. 223-224). Thus, postmodern culture is passing through a crucial stage, where signs, simulacra, and images determine human behaviour. There is a need of remapping of societal, cultural and market structures through instantaneous and omnipresent communication systems of cyberculture. Ultimately, Baudrillard visualizes this historical phase of society nearing a state of utter collapse. He argues: "Today we are not approaching the end of history but moving into reverse, into a process of systematic obliteration" (Encyclopedia of Postmodernism, 75).

\section{Conclusion}

Man has become a passive victim and is hypnotized by the obscene flow of images. Obesity and obscenity are the major problems and characteristics of postmodern culture. Fatigued and failure to bear the burden of his own belly_-burden of his own hollowness, the individual visits from clinic to clinic to reduce his weight. He is free, uncontrollable, and running with an indeterminate serpentine speed only to be steeped in perspiration and exhaustion. Why do all these things happen? Why such an electrical speed? Why such impatience, and restlessness and accumulation? A volley of other questions crops up before the contemporary man. Baudrillard responds all such questions and deduces that media, sign, code of simulation and communication makes man an escapist. Commercialization and consumption have transported men to a state of ecstasy. He has caricatured himself to a robot. In Transparancy of Evil (1990), Baudrillard forecasts a very sad state of imminent culture, seized with incurable disease, whose death is inevitable. Neither is there any remedy nor is any spiritual power, which could prevent it from decay. This state of culture is the fourth order of simulacra, which Baudrillard designated to Fractal Order. Thus, in the Chapter "Vanishing Point" of America, he declares the Death of meaning, the Death of Reality, the Death of history, the Death of the social, the Death of the political and the Death of sexuality in postmodern society.

\section{References}

Baudrillard, J. (1988). America. London \& New York: Verso.

Encyclopedia of Postmodernism.

Ibid. (p. 104).

Kelly, M. (1998). Encyclopedia of Aesthetics. New York: Oxford University Press.

McGuigan, J. (1999). Modernity and Postmodern Culture. Philadelphia: Open University Press.

Powell, J. (1998). Modernism. Chennai: Orient Longman Ltd.

Surber, J. P. (1998). Culture and Critique. Colorado: Western Press.

Taylor, V. E., \& Winguist, C. E. (Eds.). (2001). Encyclopedia of Postmodernism. London \& New York: Routledge.

\section{Copyrights}

Copyright for this article is retained by the author(s), with first publication rights granted to the journal.

This is an open-access article distributed under the terms and conditions of the Creative Commons Attribution license (http://creativecommons.org/licenses/by/4.0/). 